\title{
Nurses' Performance Regarding Caring of Patients Undergoing Blood Transfusion
}

\author{
Muhammad Saied Saif Al-Nasr ; Dr. Bahia Galal Abd-El Razik ; Prof. Magda Abd-El \\ Aziz Mohamed; Prof. Mamdouh Mohamed Al-Mezaien . \\ Demonstrator in Medical Surgical Nursing Department, Port-Said University. Lecturer of \\ Medical Surgical Nursing, Faculty of Nursing, Port-Said University; Professor of Medical \\ Surgical Nursing, Faculty of Nursing, Ain-Shams University; Professor of General and Vascular \\ Surgery, Faculty of Medicine, Suez Canal University.
}

\begin{abstract}
Background: Blood transfusion is an essential component of modern health care that saves millions of lives each year, and it will continue to be so for many years to come. Aim : the current study aimed to assess nurses' performance regarding nursing care of patients undergoing blood transfusion. Subjects and Methods : A descriptive research design was utilized in this study. The study was carried out at three hospitals affiliated to the Ministry of Health (Port-Said General Hospital, Port -Fouad General Hospital, and ElZohoer Centeral Hospital). The study sample composed of 134 nurses. The data were collected using three tools (a structured interview sheet for knowledge, nurses' attitude questionnaire and an observational checklist for practice. Results: The results of the present study revealed that there were highly statistically significant relations between the studied nurses' total knowledge mean scores and total practice mean scores with their educational level with $p \leq 0.001$. In addition ,there was a highly positive statistically significant correlation between the studied nurses' total knowledge mean scores and their total practice mean scores with $p \leq 0.00$.Conclusion : Based on the results of the present study, it can be concluded that, the majority of the studied nurses have unsatisfactory level of knowledge and less than three-quarters of them have unsatisfactory level of practice with more than the half of them have positive attitudes regarding nursing care of patients undergoing blood transfusion. It was recommended that educational training programs should be provided to nurses to improve their level of knowledge and practice about nursing care provided to patients undergoing blood transfusion.
\end{abstract}

Key words: Nurses' Performance, Blood Transfusion. 


\section{INTRODUCTION}

Blood component therapy is frequently used to manage hematologic diseases. Many therapeutic and surgical procedures depend on blood product support. However, blood component therapy only temporarily supports the patient until the underlying problem is resolved. Because transfusions are not free from hazards, they should be used only if necessary (Lewis et al., 2014). Along similar lines, blood transfusion is a lifesustaining and life-saving treatment, but they aren't without risk. Conditions that warrant blood transfusions range from acute trauma to intra-operative blood loss to compromised blood-cell production secondary to disease or treatment (Bielefeldt $\boldsymbol{\&}$ DeWitt, 2009).

Blood transfusion is defined as " administration of whole blood and blood components with knowledge of correct administration techniques and preventing possible complication" (Hinkle \& Cheever, 2014). Moreover, it's an administration of whole blood and blood components to increase the amount of oxygen being delivered to the tissues and organs (Nettina, 2014).

Blood transfusion in general has been and will most probably remain a life-saving intervention for decades to come. Critically ill patients are frequently transfused, with $40-50 \%$ of patients receiving a red blood cell transfusion during their stay in the intensive care unit (Juffermans \& Walsh, 2015). The decision to transfuse is not just dependent on laboratory parameters, such as the hemoglobin level, platelet count or clotting screen, but requires a careful assessment of the patient's overall clinical status (Hoffbrand et al., 2016).

Transfusion reactions are unintended responses in a patient which are associated with the transfusion of blood or blood component. These reactions may be fatal, lifethreatening, incapacitating and result in prolonged hospitalization and morbidity. A transfusion reaction requires immediate recognition and prompt nursing action to prevent further complication if patient is unconscious or so heavily sedated that he/she can't report the common symptoms (Abramovitz et al.,2013).

The nurse if responsible for all aspects of blood transfusion therapy and must continually assess patient's response to the transfusion. Knowledge specific to blood transfusions includes blood types, blood component therapy. Administration equipment, and specific techniques for administering each component ( Osborn et al., 2010).

The nurse who is at the point-of-care and therefore has an essential role in patient safety during a blood transfusion and they have an opportunity to provide essential contributions to the national transfusion safety initiatives and to nursing science by conducting research that is focused on the gaps in transfusion knowledge, surveillance, and reporting transfusion adverse events (Aulbach, 2013). 
The patient history is an important component of the pre-transfusion assessment to determine the history of previous transfusions as well as previous reactions to transfusion. The history should include the type of reaction, its manifestation, the interventions required and whether any preventive interventions were used in subsequent transfusions. Moreover, a systematic physical assessment and measurement of baseline vital signs are important before transfusion (Hinkle $\&$ Cheever, 2014).

Because serious transfusion reactions generally occur within the first 5 to 15 minutes of the infusion, many health care agencies require that a nurse remains with and monitors the client during this critical time, however, nurses monitor clients frequently throughout a transfusion for signs of a reaction or other complications associated with receiving blood (Timby \& Smith, 2014).

Patients must receive only blood that is compatible with their own blood group to prevent a hemolytic reaction .Quick detection of complications can be lifesaving. It is easy to think of transfusing blood components as a routine procedure because it is a common activity. (Williams and Hopper, 2015).

Critical thinking and clinical judgment skills are necessary because the clinical manifestations of transfusion reaction are not always "text book". Therefore, the nurse is responsible for evaluating each situation and being knowledgeable about and able to respond with the appropriate care when problems occur (Osborn et al., 2010).

Many hospital transfusion protocols and related nursing practices have been based more on tradition and assumptions than on scientific evidence. The saline priming of blood transfusion tubing is one such nursing practice that has long been guided by tradition. The risks and cost related to transfusion therapy have spurred a great deal of scientific inquiry in the past 15 years .The responsibility of hospital transfusion committee is to formulate policies for proper use of blood and components , monitoring of adverse effects of transfusion, endorsing national guidelines and evidence-based practice, facilitating transfusion audit and feedback (continuous improvement), facilitating incident reporting and follow up on any errors or near misses, encouraging education/training and increasing clinical competency participating in the implementation of new technologies that enhance patient safety (Gray \& Illingworth, 2013 ).

Patient blood management(PBM)is a multidisciplinary approach to improve patient outcomes using evidence based strategies in patients who may need transfusion. The goal is not only to improve outcomes by transfusing blood appropriately ,but also to introduce strategies to prevent patients from needing a transfusion in the first place (Simon et al., 2016).

\section{Significance of the Study:}

According to Annual SHOT Report (2011), collection and administration of blood represent $40 \%$ of total fatal errors related to blood transfusion. Moreover, within the last 
sixteen years, only 14 reports of research and ten quality audits or quality improvement projects were identified that describe the blood transfusion knowledge and practice of nurses. Despite decades of nurses' involvement with blood transfusions, there is scant research to describe the practice of nurses regarding blood transfusions (Aulbach, 2013).

Based on the results of Hijji et al., (2010), Hijji et al., (2012), and Ibrahim (2012) who stated in their studies that nurses have unsatisfactory level of knowledge and inadequate practices regarding care of patients undergoing blood transfusion. Furthermore, the justification for conducting this study is the lack of nursing research in Egypt on blood transfusion practices and the national focus on transfusion safety including adverse event reporting.

\section{AIM OF THE STUDY:}

The aim of the current study was to assess nurses' performance regarding nursing care of patients undergoing blood transfusion.

\section{The Research Questions}

1. What is the nurses' performance regarding nursing care of patients undergoing blood transfusion?

2. What are the factors affecting nurses' performance regarding nursing care of patients undergoing blood transfusion?

3. Is there a relationship between nurses 'knowledge and their practice regarding nursing care of patients undergoing blood transfusion?

\section{SUBJECTS AND METHOD:}

A descriptive research design was utilized in the current study.

\section{Setting:}

This study was conducted at three hospitals affiliated to the Ministry of Health (PortSaid General Hospital, Port -Fouad General Hospital, and El-Zohoer Central Hospital). From each hospital, the following units were included: Dialysis Unit, Intensive Care Unit, Medical Department, Surgical Department and Cardiac Care Unit.

\section{Sample:}

The subjects are composed of all nurses (males \& females) who have been working at previously mentioned settings and who have providing direct care to patients undergoing blood transfusion process. The number of nurses is one hundred and thirty four (134) nurses.

\section{Tools of data collection:}

Three tools were used to collect data for this study.

TOOL (I): A Structured Interview Sheet, this tool is adapted from (Ibrahim, 2012) based on reviewing the related literatures to assess nurses' knowledge regarding care of patients undergoing blood transfusion and modified by the researcher. It composes of two parts containing open and closed ended questions to assess the following: 
Part I: This part included personal data and professional characteristics of the studied nurses; it consists of $\mathbf{1 4}$ closed-ended questions.

Part II: Nurses' knowledge regarding care of patients undergoing blood transfusion: It consists of $\mathbf{3 2}$ closed-ended questions and $\mathbf{1 2}$ open-ended questions, the questions are divided into main categories as the following : definition of blood and blood transfusion two questions; functions of blood and types of blood groups Six questions; types of blood components and its indication for transfusion Seven questions; nursing care for patients undergoing blood transfusion (before, during and after) twenty three questions and nursing care for adverse reactions of blood transfusion six questions.

\section{TOOL (II): Nurses' Attitude Questionnaire Sheet:}

This tool was developed by the researcher based on reviewing the related literature; the tool consists of $\mathbf{1 6}$ attitudinal statements which are measured on five-point Likert scale ranging from 5 to 1 for responses : strongly agree, agree, neutral, disagree and strongly disagree respectively for the positive statements number $(1,2,3,8,9,10,11,12,14$ and 15$)$ and this scoring is reversed from 1 to 5 for negative statements number $(4,5,6,7,13$ and 16$)$.

TOOL (III): An observational checklist to assess nurses' practice regarding care of patients undergoing blood transfusion,

This tool was adapted from (Ibrahim, 2012) .Certain modifications have been done by the researcher in the adopted checklists to suit the nature of the study. This tool consists of the following procedures: preparation of equipment needed for blood transfusion (17 items); pre-transfusion nurses' practices toward care of patients undergoing blood transfusion (22 items); during transfusion nurses' practices toward care of patients undergoing blood transfusion (18 items); post-transfusion nurses' practices toward care of patients undergoing blood transfusion ( 8 items) and nursing management of blood transfusion reactions (20 items).

\section{Scoring System of tools:}

\section{(A)Scoring System of Nurses' Knowledge:}

The total number of questions is $\mathbf{4 4}$ questions. A total score of $\mathbf{8 8}$ marks is given for all questions. The studied nurses' answers are compared with a model key answer, where two scores are given for completely correct answer, one for incompletely correct answer, and zero for not knowing the answer or incorrect answer. According to the nurses' responses, their level of knowledge is categorized as the following: Satisfactory level ( $\geq 75 \%$ ).Unsatisfactory level (<75\%) (Eldosoky, 2004) and (ElSoudany,2011).

\section{(B)Scoring System of Nurses' Attitude:}

For the $\mathbf{1 6}$ statements, total scores that can be achieved ranged from $\mathbf{1 6}$ to $\mathbf{8 0}$. Scores between 16 and $\mathbf{6 0}$ are considered as negative attitudes $(<75 \%)$ and scores higher than 60 are considered as positive attitudes( $\geq 75 \%$ ).

\section{( C) Scoring System of Practice :}

The total scores of nurses' practice are $\mathbf{1 7 0}$ marks of $\mathbf{8 5}$ items for all the nursing procedures regarding blood transfusion. The nurses' practice is classified into two 
score for completely done, one score for incompletely done, and zero score for not done. According to the nurses' actual practice, their level of practice is categorized as the following: satisfactory level ( $\geq 75 \%)$, unsatisfactory level $(<75 \%)$. (Eldosoky,

2004) and (El-Soudany, 2011).

\section{Content Validity of the tools :}

For the tool of Nurses' Attitude Questionnaire Sheet, content validity is ascertained by 13 experts in the field of medical surgical nursing and medicine (internal medicine and clinical pathology) (Appendix II). Necessary modifications are done according to the experts' opinions. As regards the adapted tools of Structured Interview Sheet for knowledge and observational checklist for practice, the content validity of them are tested by (Ibrahim, 2012) as follows ( $81.8 \%$ and $90.9 \%$, respectively).

\section{Reliability of Tools:}

For the tool of Nurses' Attitude Questionnaire Sheet, it is held on (15 nurses) from total number of nurses in Port-Said General Hospitals. Cronbach's alpha coefficient is used to assess the internal consistency of attitude and its value was (0.77). As regards the adapted tools of Structured Interview Sheet for knowledge and observational checklist for practice, the reliability of them are tested by (Ibrahim, 2012) as follows ( $88 \%$ and $89 \%$, respectively).

\section{Pilot Study:}

A Pilot study is carried out on $\mathbf{1 0} \%$ of total number of nurses (15) who have been working at Port-Said General Hospital, Port -Fouad General Hospital, and El-Zohoer Centeral Hospital. The purpose of the pilot study is to test applicability, clarity, relevance and feasibility of study tool and sequence of quotations to maintain consistency. Also, it is used to estimate the time needed to complete the tools. The necessary modifications are done and the final form is developed. The nurses in the pilot study are excluded from the final subjects of the study.

\section{Field Work:}

The data were collected from all nurses (males \& females) who have been working at previously mentioned settings and who have been providing direct care to patients undergoing blood transfusion. The process was carried out from the beginning of June 2014 extended to the end of December 2014. The researcher has met the nurses individually and explains to them the purpose and procedure of the study and obtains oral consent, the researcher interviewing the studied nurses for 30-45 minutes and sometimes on separated periods according to duties of nurses and nature of setting to fill in the knowledge questionnaire sheet. The researcher has been available at each study setting by rotation, four days per week during morning, afternoon and night shifts (night shift only June, July and August 2014) except in Dialysis Units (morning and afternoon shifts).As regards measuring attitude, the questionnaires are distributed among nurses in three shifts (morning, afternoon and night shifts) and nurses filled them in by themselves ( self-administered questionnaire). Every nurse was observed on two different occasions and in different shifts during their actual practice and the 
average of observation is used but collected data are entered for one time. Although in this study, the researcher observes pre, during and post-transfusion to obtain valid and reliable data regarding nurses' practice about blood transfusion according to the type of blood component such as, transfusion of whole blood takes from 3.5 to 4 hours, packed RBCs takes from 90 to 120 minutes, and plasma or platelets takes from 30 to 45 minutes. Moreover the researcher reports signs and symptoms of acute complication after blood transfusion process (40 cases are reported).

\section{Ethical consideration:}

Each study subject has the freedom to be involved in the study or to withdraw at any time. The research investigator assures that the information obtained is confidential and to be used only for purpose of the study. A consent is obtained orally from the nurses under the study, ensuring complete privacy and total confidentially.

Statistical analysis : data were analyzed with SPSS version 16 . The normality of data was first tested with one-sample Kolmogorov-Smirnov test. Qualitative data was described using number and percent. Continuous variables were presented as mean \pm SD (standard deviation) for parametric data and median for non-parametric data. The two groups were compared with Student $\boldsymbol{t}$ test (parametric data). Analysis of variance (ANOVA test) used for comparison of means of more than two groups. Pearson correlation is used for assessing correlation between knowledge, attitude and practice of studied nurses

\section{RESULTS:}

Table (1): reveals that more than the half of studied nurses (52.2\%) are in age group of $20-<30$ years old with mean age of $30.9 \pm 4.4$ years. Less than two-thirds of nurses $(60.4 \%)$ are graduated from secondary school diploma of nursing and $21.6 \%$ of them are graduated from bachelor's degree. Married nurses constitute $61.9 \%$ of the study subjects.

Figure (1): illustrates that $91.8 \%$ of the study nurses have unsatisfactory total knowledge scores regarding blood transfusion.

Figure (2): represents that $51.5 \%$ of the studied nurses have positive responses regarding their total scores of attitude.

Figure (3): shows that $73.9 \%$ of studied nurses have unsatisfactory level in their total scores of practice.

Table (2): reveals that $91 \%$ have unsatisfactory level regarding general knowledge score and $86.5 \%$ have unsatisfactory level regarding blood transfusion process. In addition, $82.1 \%$ of nurses have unsatisfactory level regarding care of patients undergoing blood transfusion nursing. Moreover , 91.8 of studied nurses have unsatisfactory level regarding nursing care of blood transfusion complication with total unsatisfactory knowledge level $(91.8 \%)$ and total mean+ SD ( \%) 56.5 \pm 11.7 . As regarding nurses' attitude toward blood transfusion, $51.5 \%$ of studied nurses had positive responses in their total scores of attitude and $48.4 \%$ had negative responses with total Mean +SD (\%) 75.2 \pm 6.0 . 
Concerning nursing practice, more than three-quarters $(77.6 \%)$ of nurses have unsatisfactory level regarding preparation of equipments prior to blood transfusion. Also, 67.2\%, 58.2\% and 92.5\%, nursing care practice before blood transfusion, nursing care practice during blood transfusion and management of transfusion complication respectively. But, $92.6 \%$ of them have satisfactory level regarding nursing care practice after blood transfusion with total unsatisfactory practice level $73.9 \%$ and total Mean \pm SD (\%) 69.4 \pm 8.0 .

Table (3): proves that there is a highly statistically significant positive correlation between nurses' total knowledge mean scores and their total practice mean scores with $p$ $\leq 0.0001$. Furthermore, there is a highly statistically significant positive correlation between nurses' total knowledge mean scores and their total attitude mean scores with $p$ $\leq 0.0001$. The same table shows that there are no statistically significant relations between nurses' practice means scores in relation to their total attitude mean scores.

Table (1): Personal Characteristics of the Studied Nurses (N=134)

\begin{tabular}{|c|c|c|}
\hline \multirow{2}{*}{ Personal characteristics } & \multicolumn{2}{|c|}{ Studied nurses $(n=134)$} \\
\hline & No. & $\%$ \\
\hline \multicolumn{3}{|l|}{ Gender } \\
\hline Male & 4 & 3.0 \\
\hline Female & 130 & 97.0 \\
\hline \multicolumn{3}{|l|}{ Age (years) } \\
\hline $20-<30$ & 70 & 52.2 \\
\hline $30-<40$ & 56 & 41.8 \\
\hline$\geq 40$ & 8 & 6.0 \\
\hline Min-Max Range & \multicolumn{2}{|c|}{$24.0-42.0$} \\
\hline Mean \pm SD & \multicolumn{2}{|c|}{$30.9 \pm 4.4$} \\
\hline \multicolumn{3}{|l|}{ Educational level } \\
\hline Secondary School Diploma of Nursing & 81 & 60.4 \\
\hline Technical Institute/Nursing & 17 & 12.7 \\
\hline Health Technical Institute & 2 & 1.5 \\
\hline Bachelor's Degree & 29 & 21.6 \\
\hline Master Degree & 5 & 3.7 \\
\hline \multicolumn{3}{|l|}{ Marital status } \\
\hline Single & 45 & 33.6 \\
\hline Married & 83 & 61.9 \\
\hline Divorced/Widow & 6 & 4.5 \\
\hline
\end{tabular}


Figure (1): Total knowledge Scores among the Studied Nurses Regarding Care to Patients Undergoing Blood Transfusion ( $\mathrm{N}=134)$.

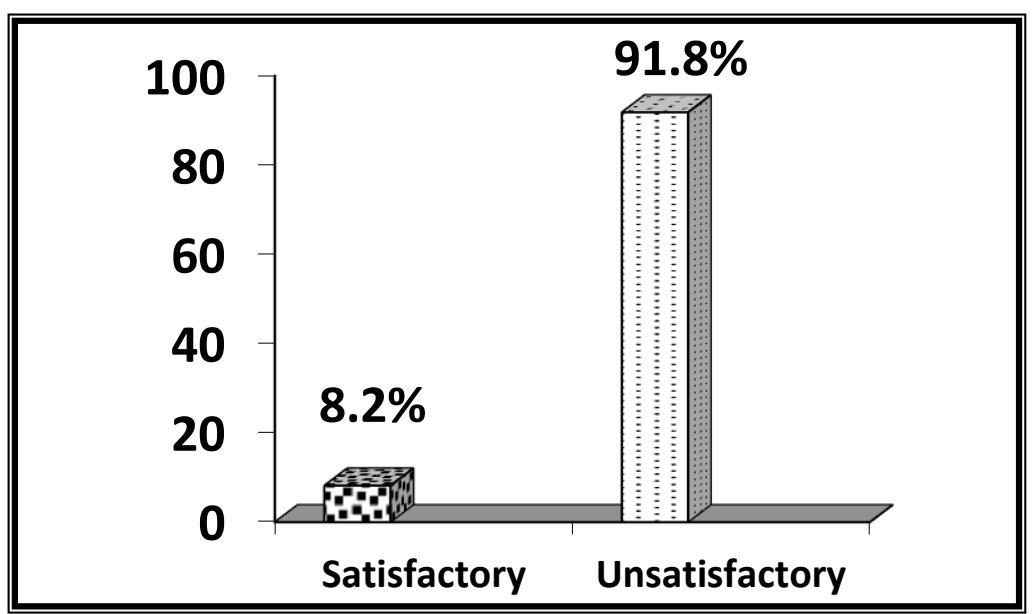

Figure (2): Level of Attitude among the Studied Nurses Regarding Nursing Care to Patients Undergoing Blood Transfusion (N=134).

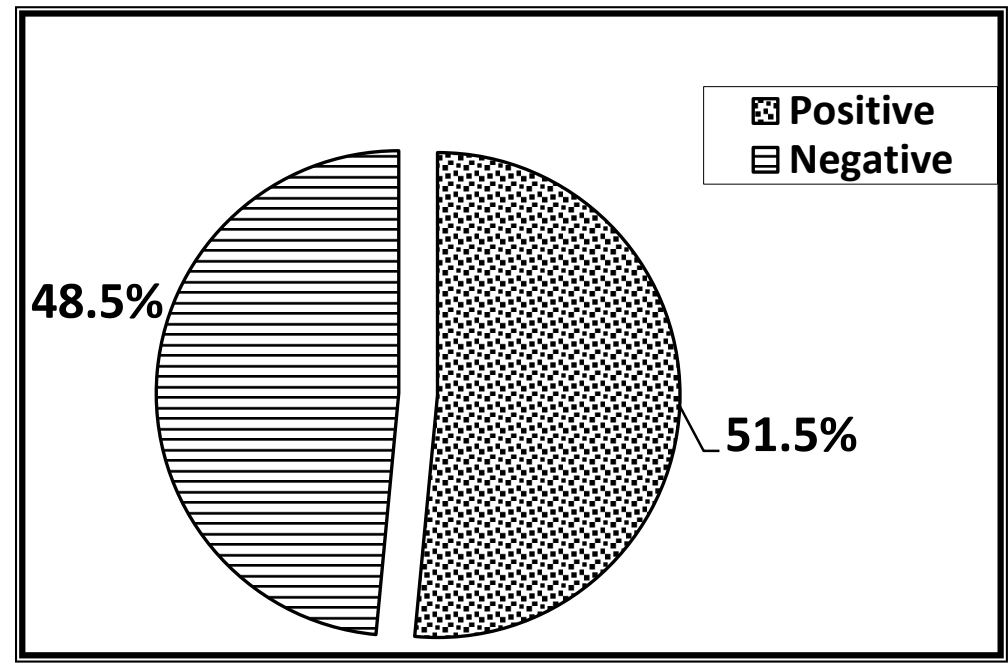

Figure (3): Level of Practice among the Studied Nurses Regarding Nursing Care to Patients Undergoing Blood Transfusion $(\mathrm{N}=134)$

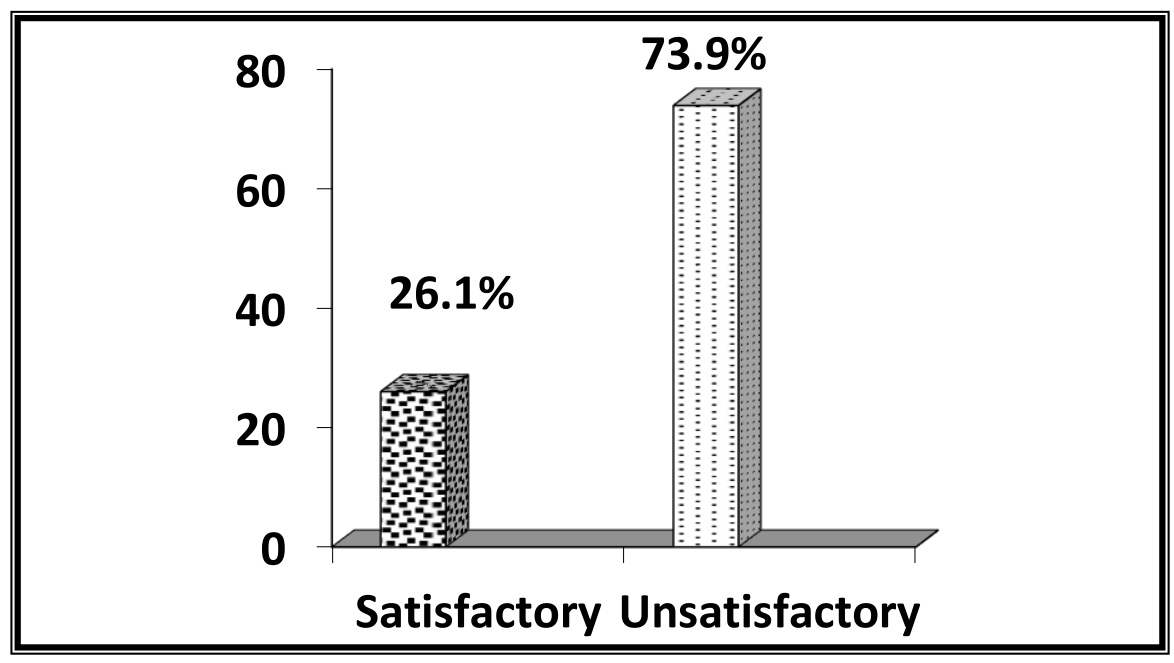


Table (2): Scores of Nurses' Knowledge, Attitude and Practice regarding caring of patients Undergoing Blood Transfusion among Studied Nurses ( $=134)$.

\begin{tabular}{|c|c|c|c|c|c|c|}
\hline \multirow{3}{*}{$\begin{array}{c}\text { Knowledge, Attitude, and Nursing } \\
\text { Practice }\end{array}$} & \multicolumn{6}{|c|}{ Score $(\%)$} \\
\hline & \multirow[b]{2}{*}{ Min-Max } & \multirow{2}{*}{$\begin{array}{c}\text { Mean } \\
\pm \text { SD } \\
(\%)\end{array}$} & \multicolumn{2}{|c|}{ Less than $75 \%$} & \multicolumn{2}{|c|}{$75 \% \leq$} \\
\hline & & & No. & $\%$ & No. & $\%$ \\
\hline $\begin{array}{c}\text { Knowledge about blood transfusion } \\
\text { scores }\end{array}$ & & & \multicolumn{2}{|c|}{ Unsatisfactory } & \multicolumn{2}{|c|}{ Satisfactory } \\
\hline General knowledge score & $18.8-93.8$ & $45.1 \pm 15.9$ & 122 & 91.0 & 12 & 9.0 \\
\hline Blood transfusion process score & $21.4-100.0$ & $53.9 \pm 16.9$ & 116 & 86.5 & 18 & 13.4 \\
\hline $\begin{array}{l}\text { Care for patients receiving blood } \\
\text { transfusion score }\end{array}$ & $37.0-89.1$ & $63.0 \pm 11.2$ & 110 & 82.1 & 24 & 17.9 \\
\hline $\begin{array}{l}\text { Nursing care of complication of blood } \\
\text { transfusion }\end{array}$ & $8.3-91.7$ & $50.2 \pm 14.5$ & 123 & 91.8 & 11 & 8.2 \\
\hline Total score & $29.5-85.2$ & $56.5 \pm 11.7$ & 123 & 91.8 & 11 & 8.2 \\
\hline $\begin{array}{c}\text { Attitude towards nursing care in blood } \\
\text { transfusion score }\end{array}$ & & & \multicolumn{2}{|c|}{ Negative } & \multicolumn{2}{|c|}{ Positive } \\
\hline & $58.8-95.0$ & $75.2 \pm 6.0$ & 65 & $\begin{array}{c}48 . \\
5\end{array}$ & 69 & 51.5 \\
\hline Nursing practice score & & & \multicolumn{2}{|c|}{ Unsatisfactory } & \multicolumn{2}{|c|}{ Satisfactory } \\
\hline Preparation of equipments score & $50.0-82.4$ & $67.9 \pm 8.2$ & 104 & 77.6 & 30 & 22.4 \\
\hline Pre-transfusion nursing practice score & $54.5-90.5$ & $71.4 \pm 8.9$ & 90 & 67.2 & 44 & 32.8 \\
\hline During transfusion nursing practice score & $47.2-94.4$ & $71.7 \pm 9.7$ & 78 & 58.2 & 56 & 41.8 \\
\hline $\begin{array}{l}\text { Post- transfusion nursing performance } \\
\text { score }\end{array}$ & $68.8-100.0$ & $81.7 \pm 7.5$ & 10 & 7.4 & 123 & 92.6 \\
\hline $\begin{array}{l}\text { Management of transfusion } \\
\text { complication score }\end{array}$ & $27.5-80.0$ & $50.2 \pm 14.9$ & 37 & 92.5 & 3 & 7.5 \\
\hline Total practice score & $51.2-87.3$ & $69.4 \pm 8.0$ & 99 & 73.9 & 35 & 26.1 \\
\hline
\end{tabular}


Table (3): Correlation between Scores of Knowledge, Attitude, and Nursing Practice Regarding Care of Patients Undergoing Blood Transfusion Among Studied Nurses $(\mathrm{N}=134)$.

\begin{tabular}{|c|c|c|c|c|c|c|}
\hline \multirow{2}{*}{$\begin{array}{l}\text { Knowledge, attitude, and nursing } \\
\text { performance }\end{array}$} & \multicolumn{2}{|c|}{$\begin{array}{l}\text { Total Knowledge } \\
\text { Score }\end{array}$} & \multicolumn{2}{|c|}{ Attitude Score } & \multicolumn{2}{|c|}{ Total practice Score } \\
\hline & $\mathbf{r}$ & $\mathbf{P}$ & $\mathbf{r}$ & $\mathbf{P}$ & $\mathbf{r}$ & $\mathbf{P}$ \\
\hline \multicolumn{7}{|l|}{$\begin{array}{r}\text { Knowledge about blood transfusion } \\
\text { scores }\end{array}$} \\
\hline General knowledge score & - & - & 0.359 & $<0.0001 * * *$ & 0.605 & $<0.0001 * * *$ \\
\hline Blood transfusion process score & - & - & 0.490 & $<0.0001 * * *$ & 0.354 & $<0.0001 * * *$ \\
\hline $\begin{array}{l}\text { Care for patients receiving blood } \\
\text { transfusion score }\end{array}$ & - & - & 0.318 & $<0.0001 * * *$ & 0.657 & $<0.0001 * * *$ \\
\hline $\begin{array}{l}\text { Nursing care of complication of blood } \\
\text { transfusion }\end{array}$ & - & - & 0.544 & $<0.0001 * * *$ & 0.534 & $<0.0001 * * *$ \\
\hline Total score & - & - & 0.453 & $<0.0001 * * *$ & 0.651 & $<0.0001 * * *$ \\
\hline \multicolumn{7}{|l|}{ Nursing practice scores } \\
\hline preparation of equipments score & 0.482 & $<0.0001 * * *$ & -0.02 & 0.822 & - & - \\
\hline Pre-transfusion nursing performance score & 0.777 & $<0.0001 * * *$ & 0.334 & $<0.0001 * * *$ & - & - \\
\hline $\begin{array}{l}\text { During transfusion nursing performance } \\
\text { score }\end{array}$ & 0.600 & $<0.0001 * * *$ & 0.129 & 0.138 & - & - \\
\hline $\begin{array}{l}\text { Post- transfusion nursing performance } \\
\text { score }\end{array}$ & 0.536 & $<0.0001 * * *$ & 0.106 & 0.223 & - & - \\
\hline Management of complication score & -0.058 & 0.724 & -0.072 & 0.658 & - & - \\
\hline Total practice score & 0.651 & $<0.0001 * * *$ & 0.09 & 0.299 & - & - \\
\hline
\end{tabular}

r: Pearson correlation coefficient $\quad$ *significant at $\mathrm{P} \leq 0.05 * * *$ extremely high significant at $p \leq$ 0.0001

\section{DISCUSSION:}

Concerning total score of nurses ' knowledge regarding to care of patients undergoing blood transfusion, the findings of this study revealed that there was a marked unsatisfactory level in their total knowledge. This result is supported by Hijji et al.( $\mathbf{2 0 1 2 b}$ ), who mentioned that, nurses have significant knowledge deficits of many aspect of blood transfusion. It may be that identifying knowledge gaps prevents effective surveillance or reporting and proposing strategies for closing these gaps.

The present study results revealed that, regarding to nurses' knowledge topics related to blood transfusion, the majority of studied nurses have unsatisfactory level of knowledge regarding definition of blood transfusion, blood components, blood functions and nursing care for patients receiving blood transfusion, Along similar lines, Ibrahim (2012), who stated that the majority of nurses in her study had unsatisfactory level of knowledge regarding these items before implementing of her nursing guidelines. In agreement with the previous finding Lewis et al.(2007) emphasized that the nurse must be knowledgeable about what to include in the health 
history so that questions may be phrased in a manner eliciting the information related to the hematological problem. It could be that Lack of knowledge of various aspects of blood transfusion by clinical staff, including nurses, continues to be a real threat to patient safety. Therefore, nurses must provide high quality care and function effectively and they must have an adequate knowledge that they have actually used in practice .

Regarding to general knowledge about blood transfusion items such as, types of blood groups; blood components; and blood functions, this study result revealed that the majority of nurses had an unsatisfactory level of knowledge. These results in agreement with Hijji et al. (2012a), who stated that the majority of nurses have unsatisfactory level of knowledge regarding types of blood groups and lack knowledge about basic ABO terminology. It may be that nurses should be knowledgeable about blood groups that are of great clinical importance in blood transfusion, in fact ; the discovery of $\mathrm{ABO}$ system is one of the most important contributions in the safety and practice of blood transfusion.

Concerning nurses' knowledge about nursing care for blood transfusion complication , the result of this study revealed that the majority of nurses had marked unsatisfactory level of knowledge .These results are congruent with Ibrahim (2012), who mentioned in her study that all nurses have no knowledge regarding complication of blood transfusion before implementation her nursing guidelines. Likewise, Aslani et al. (2010), reported that it is recommended to activate the blood transfusion committee in hospitals to increase the quality of this common procedure and prevent side effects by in-service trainings of nurses. It may be a must for nurses to have the knowledge of pathophysiology of transfusion reactions, symptoms and management that can improve patient's monitoring. Also, the hospital should have a transfusion committee that is concerned with improving blood transfusion practice. This committee should be involved in implementing blood transfusion protocols, updating guidelines on blood transfusion, following up the application of such guidelines by the physicians in different wards, and investigating any near miss

In the light of present study, it was found that the majority of the studied nurses had positive attitudes regarding the role of nurses in blood transfusion process, the importance of written consent from physician, identification of patients with viral hepatitis, compatibility and blood typing reduce the incidence of complication and informing the responsible physician and blood bank when complications occur. Nonetheless, the results of the present study revealed that the majority of the study nurses had negative attitudes toward documentation of blood transfusion complication when occur. These findings may be related to the fact that nurses did not disclose any mistake to their supervisors and patients' family members because they were worried about their reactions if any harm would occur to the patient. In addition, she /he will be considered as an incompetent nurse. So, they still feel threatened from reporting their mistakes to supervisors and physicians. 
From the researcher point of view, these behavioral changes are required and nurses need to teach themselves through accessing different resources on blood transfusion, and learning about aspects relevant to their practice. However, knowledge, on its own, does not guarantee safe practice unless other personal (i.e. positive attitudes) and organizational (e.g. time, nurse to patients ratio, materials) barriers were effectively addressed .

In the light of the present study findings, less than three-quarters of nurses had unsatisfactory total score of practice regarding nursing care of patients undergoing blood transfusion. These results are supported by Ibrahim (2012), who stated that none of the nurses in her study have an adequate practices regarding blood transfusion. on the same context, de Graaf et al., (2009) reported that the poor blood transfusion practice is likely to play a role in the morbidity and mortality of patients who receive a blood transfusion. This may be related to the fact that the gap in nursing practice is increased due to inadequacy of adherence to evidence-based guidelines and explained by the lack of training programs and in-services training for nurses, overlapping for work that in some units where data was collected, there is only one fixed nurse for every shift who has been responsible for all blood transfusion process and its equipment preparation for more than one unit according to his condition to one patient or transfusing blood to more than patients at the same time, shortage of equipment in the hospital and lack of supervision or absence of the good role of the head nurse regarding closed observation and motivation.

The present study showed that, the majority of nurses had unsatisfactory level regarding management of transfusion complication. the nurses may believe that causes of blood transfusion reactions can be related to blood group incompatibility and not to nursing care during transfusion such as increasing patient body temperature and administering medications. Aly et al. (2009) observed that nurses usually stop blood transfusion, administer the medication and then resume the transfusion. Consequently, drugs should never be added to blood or blood products (plasma and platelets concentrate). This may be occur due to lack of current information on transfusion reaction symptoms included in the education programs and delegation of obtaining vital signs to newly- graduated staff nurses that were not educated on symptoms of a transfusion reaction. In addition, it might be that underreporting between nurses in these units can be explained by the fact that these conditions are not greatly observed. Thus, they are not easily discovered by variety of hospital personnel. Underreporting also occurs due to fear of interpersonal reactions of physicians, supervisors and patients.

All these pitfalls may be due to the lack of training which is evidenced by the results of present study, which proved that the majority of nurses under study have not attended any previous training courses

In the light of the study findings, there were statistically significant positive correlations between total score of nurses' knowledge about blood transfusion and 
total score of nurses' practices of blood transfusion. This finding is in accordance with Tabiee et al. (2001) and Purfarzad et al. (2012), who stated that there is a significant correlation between knowledge and practices of nurses. It is commonly known that knowledge retention and attitude towards blood transfusion changed over time depending on lack of training, overloaded duties and time pressure in critical situations.

\section{CONCLUSION:}

Based on the findings of the current study, the majority of the nurses under study have unsatisfactory level of knowledge and less than three-quarters of them have unsatisfactory level of practice with more than the half of them having positive attitudes regarding blood transfusion. In addition, there were highly statistically significant relations between studied nurses' total knowledge and total practice mean scores in relation to their educational level with $p \leq 0.001$. In addition, there was a highly positive statistically significant correlation between the studied nurses' total knowledge mean scores and their total practice mean scores with $p \leq 0.001$.

\section{RECOMMENDATION:}

Based on the findings of this study, the following recommendations can be suggested: periodic educational program for nurses who have been working at PortSaid General Hospitals is mandatory, for the purpose of raising and updating the knowledge of nurses; it is necessary that we provide procedure manual handbooks containing all necessary information (knowledge and practice) about nursing procedures related to blood transfusion; what should be taken into consideration is establishing hospital blood transfusion committee to be responsible for all components of blood transfusion process and reporting blood transfusion reactions; nurses should be encouraged to attend national and international conferences, workshops and training courses affiliated to Ministry of Health related to nursing care for patients undergoing blood transfusion and develop, implement, and evaluate an educational program for nurses Port-Said general hospitals regarding to nursing care of patients undergoing blood transfusion.

\section{REFERENCES:}

Abramovitz, J., Mc-Cann, A., Robinson, M., Morris, M., Stout, K., Foley, A., Moreau, D., Labus, D., \&Eckman, M. (2013). Nursing Procedures. $6^{\text {th }}$ ed., USA: Lippincott, Williams and Wilkins Company, P 747.

Aly, N.(2009). Drug administration errors and their determinates in Intensive Care Units of El-Shatby Pediatric University Hospital in Alexandria .Unpublished Master thesis, faculty of nursing, Alexandria University, PP. 90-91 
Aslani, Y., Etemadyfar, S. \& Noryan, K. (2010). Nurses' Knowledge of Blood Transfusion in Medical Training Centers of Shahrekord University of Medical Science in 2004. Iranian Journal of Nursing and Midwifery Research, 15(3), 141-144.

Aulbach, R. (2013). Nurses' Practices with Blood Transfusions in Medical-Surgical Patient Care Units of Acute Care Units. Doctorate thesis, The Graduate School, Texas Woman's University. Pp., 1,3,22,83,87.

Bielefeldt, S. \& DeWitt, J. (2009). The rules of transfusion: best practices for blood product administration. American nursing today, 4(2):27-30.

De Graaf, D., Kajji, I., Bimenya, S., Postma, J., \& Sibinga T.C. (2009). Bedside Practice of Blood Transfusion in a Large Teaching Hospital in Uganda: An Observational Study, Asia Journal of Transfusion Science; 3(2), 60-65.

Eldosoky, H. (2004). Assessment of Nurses' Knowledge and Practice about Measures to prevent deep venous thrombosis among hospitalized patients in General Hospitals of Port-Said City. Unpublished master thesis, faculty of nursing, Suez Canal University, PP. 77-78.

El-Soudany, E.(2011). Assessment of nurses' performance regarding infection control measures in caring for patient with post-operative wound. Unpublished master thesis, faculty of nursing, part-said University, PP. 69-72.

Gray, A. \& Illingworth, J. ( 2013). Right blood, Right patient, Right time: RCN guidance for improving transfusion practice. London: Royal Collage of Nursing. P. $11,13$.

Hijji, B, Parahoo, K., Hussein, M. \& Barr, O. (2012a). Knowledge of blood transfusion among nurses. Journal of Clinical Nursing, doi: 10.1111/j.13652702.2012.04078.x.

Hijji, B., Parahoo, K., Hossein, M., Barr, O. \& Murray S. (2010). Nurses' practice of blood transfusion in the United Arab Emirates: An observational study. Journal of Clinical Nursing, 19, 3347- 3357.doi:10.1111/j.1365-2702.2010.03383.x.

Hinkle, J. \& Cheever, K. (2014). Brunner \& Suddarth's: Textbook of medicalsurgical nursing $\left(13^{\text {th }}\right.$ ed.). China: Lippincott, Williams and Wilkins Company, pp. 889-894.

Hoffbrand, A., Higgs, D., Keeling, D. \& Mehta, A. (2016). Postgraduate Hematology ( $7^{\text {th }}$ ed.). UK : Wiley Blackwell, P. 214.

Ibrahim, F. (2012). Effect of Nursing Guideline Regarding Care of Patients Undergoing Blood Transfusion. Unpublished Doctorate thesis, Ain Shams Un., Fac. Nursing, P.p 46, 47. 
Juffermans, $N . \&$ Walsh, T. (2015). Transfusion in the intensive care unit (1 ${ }^{\text {st }}$ ed.). London : Springer international publishing, p. 13.

Lewis, S., Dirksen, S., \& Heitkemper, M. (2007). Medical Surgical Nursing: Assessment and Management of Clinical problems ( $7^{\text {th }}$ ed.). USA: Elsevier Mosby, Pp. 671, 679, 730 .

Lewis, S., Dirksen, S., Heitkemper, M., Bucher, L. \& Harding, M. (2014). Medical Surgical Nursing: Assessment and Management of Clinical problems $\left(9^{\text {th }}\right.$ ed.). USA: Elsevier Mosby. Chapter 31: Nursing Management Hematologic Problems, Pp. 676680.

Nettina, S. (2014). Lippincott of Manual Nursing Practice $\left(10^{\text {th }}\right.$ ed.).USA: Lippincott Williams \& Wilkins. Chapter 27: Transfusion Therapy and Blood and Bone marrow transplantation, pp.1001- 1012.

Osborn, S., Wraa, E. \& Watson, B. (2010). Medical Surgical Nursing: Preparation for Practice ( $1^{\text {st }}$ ed.). USA, New York: Pearson Education Company, P539.

Purfarzad, Z., Farahani, F., Ghamarizare, Z., Ghorbani, I., \& Zamani, M.(2012). Nurses' knowledge and practice of blood transfusion in Hospitals of Arak in 2010. The Scientific Journal of Iranian Blood Transfusion Organization, 9(3) : 337.

Simon, T., McCullough, J., Snyder, E., Solheim, B. \& Strauss, R. (2016). Rossi's Principles of Transfusion Medicine ( $5^{\text {th }}$ ed.). India: Wiley Blackwell, p.13.

Tabiee, S., M ahboubeh, N., \& Jou, S.(2001). Nurses' Knowledge and practice about blood transfusion in Birjand University of Medical Sciences' Hospitals. Journal Birjand University of Medical Sciences, 8(13) : 13-16.

Timby, B. \& Smith, N. (2014). Introductory Medical Surgical Nursing (11 th ed.). USA: Lippincott, Williams and Wilkins, PP. 145-148.

Williams, L. \& Hopper, P.(2015).Understanding Medical Surgical Nursing (5 $5^{\text {th }}$ ed.). Philadelphia PA: F.A. Davis Company. Chapter 27: Hematologic and Lymphatic System Function, Assessment and Therapeutic Measures, Pp.558-560. 


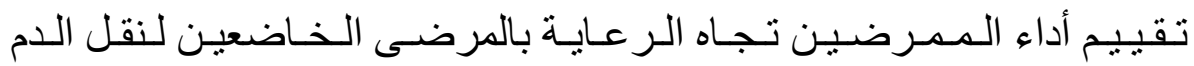

م.محمد سعيد سيف النصر; د.بهية جلال عبدالرازق; د ماجدة عبدالعزيز محمد; د ممدوح محمد المزين

معيد بكلية التهريض- جامعة بورسعيد ، مدرس التصريض الباطنى والجر/حى كلبة التهريض جامعة بورسعيد، استاذ التهريض الباطنى والجر/حى -كلية التمريض-جامعة عين شعس، استاذ الجراحة العامة والأوعية الدمويةكلية الطب- جامعة قناة السوبيس

\section{الــــلاصــة}

يعتبر نقل الدم من أهم التدخلات الطبية لإنقاذ حياة ملايين الأرواح سنويا علاوة على ذلك يستخدم نقل الدم بشكل متكرر فى علاج الأضطر ابات الدمويه. وكان الهرف من هذه الدراسة هو تقييم أداء الممرضين تجاه الرعاية التمريضية بالمرضى الخاضغين لنقل الدم ـ وقد أجريت هذة الدراسة الوصفية في وحدات الرعاية المركزة ،ر عاية القلب،الغسيل الكلوى،قم الباطنة و الجراحة بمستشفى بورسعيد العام ،الزهور المركزى وبورفؤاد العام فى محافظة بورسعيد ـ إذ تألف العينة من 134 ممرضة .وقد تم استخدام ثلاثة استبيانات لقياس معلومات وسلوك الممرضات بإستخدام إستمارة تقييم معلومات وسلوك الممرضات فى حين أنه تم تقييم ممارساتهن بإستخدام قائمة ملاحظات مهار اتهن. و أنشارت نتائج الدراسة إلى أن معظم الممرضين ذوي معلومات غير مرضية؛ في حين أن مستوى ممارسات مايقارب ثلاثة ارباعهم كان غير مرضياً و اكثر من نصفهم ذوى سلوك ايجابى. ووجدت علاقة ذات دلالة إحصائية بين معلومات الممرضات ومستو اهن التعليمي؛ وأيضاً كان هنالك علاقة ذات دلالة إحصائية بين ممارسات الممرضات ومستواهن التعليمي. وأوضحت نتائج الدراسة أن هناك علاقة ذات دلالة إحصائية عالية بين معلومات الممرضات وممارساتهن. وأوصت هذة الدر اسة بضرورة تطبيق برنامج تعليمي للممرضات فى وذللك لتحسيين مستوى معلو ماتهن وممارساتهن تجاه الرعاية التمريضية بالمرضى الخاضعين لنقل الدم.

الكلمات المرشدة : أداء الممرضين ، نقل اللدم. 